\title{
A PRELIMINARY STUDY ON THE OCCURRENCE OF KERATINOPHILIC FUNGI IN SOILS OF JAMAICA
}

\author{
Harish C. GUGNANI(1), Soni SHARMA(2) \& Kharl WRIGHT(3)
}

\begin{abstract}
SUMMARY
This report represents the first study of keratinophilic fungi present in soils of Jamaica. Out of the 40 soil samples examined from different habitats, 30 (75\%) were positive for the presence of keratinophilic fungi, yielding 36 isolates of keratinophilic fungi. Microsporum gypseum complex (represented by 16 isolates of $M$. gypseum, and four of $M$. fulvum) was most frequent, being present in $50 \%$ of the samples. A very high occurrence of this dermatophyte in Jamaican soil is of public health significance. The remaining isolates of keratinophilic fungi were represented by Chrysosporium spp (mainly C. indicum and C. tropicum) and Sepedonium sp.
\end{abstract}

KEYWORDS: Keratinophilic fungi; Microsporum gypseum; M. fulvum; Chrysosporium spp; Soil; Jamaica.

\section{INTRODUCTION}

Keratinophilic fungi are a group of fungi that colonize various keratinous substrates degrading them to components of low molecular weight. These include a variety of filamentous fungi comprising mainly hyphomycetes and several other taxonomic groups ${ }^{3}$. Hyphomycetes include dermatophytes and a variety of non-dermatophytic keratinophilic fungi ${ }^{3,10}$. Most species of dermatophytes are anthropophilic or zoophilic in their natural habitat, while some occur in soil as saprophytes and are termed geophilic, for example, Microsporum gypseum and Trichophyton terrestre $^{3,15,19}$. Non-dermatophytic keratihnophilic fungi, including species of Chrysosporium and other genera of fungi, are known to occur as saprobes in soil; some of them are potential pathogens of humans and animals ${ }^{3,10}$. Studies on keratinophilic fungi of soils of varying habitats in different countries have demonstrated frequent occurrence of Chrysosporium spp and dermatophytes like Microsporum gypseum complex (M. gypseum and M. fulvum), Trichophyton terrestre, and Trichophyton ajelloi $i^{1-5,10-13,19}$. Other dermatophytes known to occur infrequently or sporadically in soil in some countries are $M$. cookei, $M$. vanbreuseghemi, and T. gloriae ${ }^{3}$. Trichophyton simii, T. mentagrophytes, $M$. nanum and $M$. persicolor, well-known zoophilic dermatophytes, have also been frequently recovered from soil in some countries ${ }^{3,9,11,15,18,19,22}$.

Information on the prevalence of keratinophilic fungi in the West Indies is scanty and limited to only a few reports, one each from Abaco Island in Bahamas ${ }^{22}, \mathrm{Cuba}^{16}$, and St. Kitts and Nevis ${ }^{12}$. There is no report on isolation of keratinophilc fungi including dermatophytes from Jamaican soil. Thus it was considered of interest to investigate the occurrence of keratinophilic fungi in soils from different kinds of habitats in Jamaica.

\section{MATERIAL AND METHODS}

Area of study: Jamaica lies between the latitudes 170 and $190 \mathrm{~N}$, and longitudes 760 and $7 \mathrm{~W}$. Jamaica is a limestone plateau, with an average elevation of about $460 \mathrm{~m}(1500 \mathrm{ft})$. The interior of the island is mountainous and peaks of over $2100 \mathrm{~m}(7000 \mathrm{ft})$ are found in the Blue Mountains, which dominate the eastern part of the island. The coastal plains are largely alluvial and the largest plains areas lie along the south coast. The climate in Jamaica is largely tropical with hot humid weather, although higher inland regions are relatively temperate. Jamaica can be divided into 14 parishes. Samples were collected from localities in some of the parishes, viz. May Pen in the parish Clarendon, New Green, Northern Caribbean University (NCU) in Mandeville in the Manchester parish in the Middlesex county, from Montago Bay in the Saint James Parish, and Beach soil in Saint Elizabeth parish in the Cornwall County, and Kingston Harbor in the parish Kingston Surrey county. These areas are warm tropical with a relative humidity of approximately $70-80 \%$. The temperature in the greater part of the year is $22-30^{\circ} \mathrm{C}$. Jamaica receives annual rainfall of $811 \mathrm{~mm}$.

Collection of soil samples: Soil samples were collected from a depth of approximately 4-6 inches in zip polythene bags during December 2011 to February 2012, with the help of a stainless steel spatula, 6" inch long and 2" wide disinfected with $70 \%$ isopropyl alcohol each time before and after use. The polythene bags were sterilized with $70 \%$ isopropyl alcohol and left to dry for 3-4 minutes. Following this, the inside of each bag was rubbed with a sterile swab, which was then rolled on a plate of Sabouraud dextrose agar (SDA) (HiMedia Laboratories, Mumbai, India). The SDA plates were incubated at room temperature for 4-5 days. No growth of molds occurred; however, in some of the plates single bacterial colonies were observed. Thus the sterility of the zip polythene bags was

$(1)^{*},(2),(3)^{* *}$ Windsor University School of Medicine, Cayon, St. Kitts (West Indies).

*Present address: Saint James School of Medicine, Kralendjik, Bonaire (Dutch Caribbean), WI.

**Present address: Kristian woeCircel, Cedar Wood Grove estate, Mandeville, Manchester, Jamaica, (WI).

Correspondence to: Harish C. Gugnani. E-mail: harish.gugnani@gmail.com 
Table1

Species of keratinophilic fungi recovered from soils of different habitats in Jamaica

\begin{tabular}{|c|c|c|c|c|c|c|c|c|c|}
\hline \multirow{2}{*}{ Locality/ies } & \multirow{2}{*}{ Habitat } & \multirow{2}{*}{$\begin{array}{c}\text { No. samp. } \\
\text { exam. }\end{array}$} & \multicolumn{7}{|c|}{ No. positive for different species } \\
\hline & & & M. gypseum & M. fulvum & C. indicum & C. tropicum & C. keratin & Chrys. sp & Seped. sp \\
\hline $\begin{array}{l}\text { New Green Manchester } \\
\text { Cedar grove, Hat field }\end{array}$ & $\begin{array}{l}\text { Aviary- } \\
\text { pigeons }\end{array}$ & 3 & 2 & & 2 & 2 & & & \\
\hline Maypen, Osbane stone & Poultry farm & 2 & - & - & 1 & - & - & - & - \\
\hline $\begin{array}{l}\text { Hat field, New Green } \\
\text { Manchester, Georges Dulke, } \\
\text { Dembigh, Clarendon }\end{array}$ & $\begin{array}{c}\text { Animal } \\
\text { habitat (Cow, } \\
\text { goat, pig, dog, } \\
\text { horse) }\end{array}$ & 15 & 7 & 4 & 3 & 1 & 1 & 2 & 1 \\
\hline Mandville, Dorus & Garden soil & 3 & 2 & - & - & - & - & - & 1 \\
\hline $\begin{array}{l}\text { Ensula, St. Elizabeth, } \\
\text { Wontago Bay }\end{array}$ & Beach soil & 3 & 1 & - & - & - & - & - & - \\
\hline Maypen & $\begin{array}{l}\text { Sugar-cane } \\
\quad \text { field }\end{array}$ & 2 & - & - & - & - & - & - & - \\
\hline Maypen & $\begin{array}{c}\text { Banana } \\
\text { plantation }\end{array}$ & 2 & 1 & - & - & - & - & - & - \\
\hline NCU, Bonitocres, Ingle side & Bamboo Trees & 4 & 1 & & 1 & 1 & & & \\
\hline Kingston & Harbor & 2 & - & - & - & - & - & - & - \\
\hline NCU, Manchester & Potato field & 2 & 1 & & & & & & \\
\hline \multirow[t]{2}{*}{ NCU, Manchester } & Clay & 2 & 1 & & & & & & \\
\hline & Total & 40 & $16(40 \%)$ & $4(10 \%)$ & $7(17.5 \%)$ & $4(10 \%)$ & $1(2.5 \%)$ & $2(5 \%)$ & $2(5 \%)$ \\
\hline
\end{tabular}

Samp. - samples; exam. - examined; M. - Microsporum; C - Chrysosporium; Chrys. - Chrysopsorium; Seped. - Sepedonium

ensured for the purpose of this study. The collected soil samples were shortly transported to St. Kitts. For determining the approximate $\mathrm{pH}$ of the soil samples, a small quantity of the sample was suspended in distilled water five times its volume, its $\mathrm{pH}$ was determined with the help of $\mathrm{pH}$ indicator strips, and then confirmed by testing with a $\mathrm{pH}$ meter. The $\mathrm{pH}$ of the samples varied from 5.5 to 6.2. The types of soil samples collected are shown in the table 1.

Processing of soil samples and identification of isolates: Samples were processed in the Microbiology laboratory of Windsor University School of Medicine, Cayon, St. Kitts. The well-known hair-baiting technique of VANBREUSEGHEM ${ }^{21}$ was employed. For this, pieces of human hair 0.6 to $1.6 \mathrm{~cm}$ in length (sterilized by autoclaving), were spread on the soil samples in sterile Petri dishes. Small quantities of sterile distilled water $(10-15 \mathrm{~mL})$ were poured on the hair-baited plates. The plates were incubated at room temperature on the laboratory bench under normal light. Sterile water was added periodically to provide moisture needed for fungal growth. Fungal growths appearing on hair baits after 2-4 weeks of incubation were microscopically examined and cultured on slopes of Mycobiotic agar (Neogen Corporation, Lansing, Michigan, USA) to get pure cultures. Identification of the isolates was accomplished by studying the colonial and microscopical characters of the isolates in detail and comparing them with descriptions of suspected fungi in standard books and manuals ${ }^{3,7,15,20}$.

\section{RESULTS}

The distribution of keratinophilic fungi recovered from soil samples collected from different habitats is shown in the Table 1 . Thirty of the 40 samples were positive for keratinophilic fungi with mixed growth in six of the samples, thus yielding a total of 36 isolates. Microsporum gypseum complex was the most frequently isolated keratinophilic fungus being present in $50 \%$ of the samples. The majority of the isolates of this species complex originated from soil samples collected from habitats of cows, goats, pigs, dogs and horses. Out of the 20 isolates of the M. gypseum complex, 16 of them were identified as $M$. gypseum, and the remaining four as M. fulvum. The differentiation of $M$. gypseum and M. fulvum was based on phenotypic characteristics. The isolates of $M$. gypseum formed buff to cinnamon-colored colonies with yellow-brown pigment on the reverse. Microscopic examination of lactophenol blue mounds of growth demonstrated characteristic thin, rough-walled macroconidia with slightly rounded terminal ends, and truncated proximal ends (Fig. 1), characteristic of M. gypseum. ${ }^{3,7,15}$. The isolates of M. fulvum formed buff to pinkish-buff colored colonies with the reverse colorless to yellow-brown. Microscopically numerous, thin, rough-walled, and relatively longish and bullet shaped macroconidia (Fig. 2), characteristic of the species ${ }^{3,7,15}$ were observed in lactophenol blue mounds of the growth. Abundant pyriform to clavate microconidia were also seen in both species of the complex.

Chrysosporium was represented by 14 isolates, seven identified as $C$. indicum, four as $C$. tropicum, one as $C$. keratinophilum, and two as unidentified Chrysosporium sp. Two isolates were identified as Sepedonium sp. Chrysosporium species formed moderately fast growing, cream-colored colonies, dense or powdery at the center. Conidia were hyaline, smooth-walled sessile or on short protrusions or short branches. Species differentiation was done according to characteristics of conidia ${ }^{3,20}$. C. indicum isolates were characterized by sub-hyaline, smooth, thin-walled, obovoid, ellipsoidal conidia, frequently elongated, 


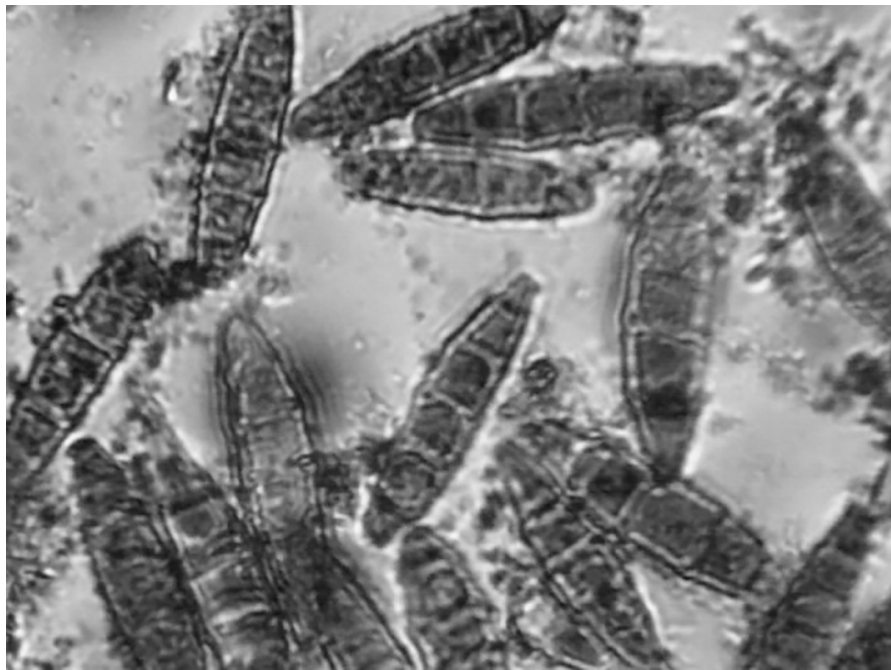

Fig. 1 - Macroconidia of a soil isolate of M. gypseum with slightly rounded terminal ends, and truncated proximal ends. Lactophenol blue mound, $\mathrm{x} 475$

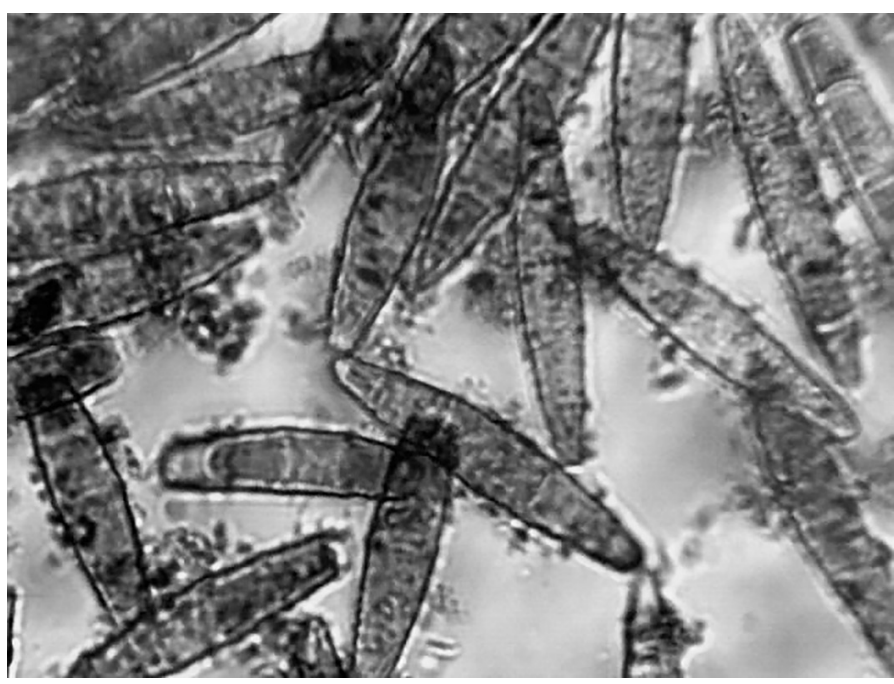

Fig. 2 - Macroconidia of a soil isolate of M. fulvum, longish and bullet shaped. Lactopheno blue mound, $\mathrm{x} 475$

less than $3 \mu \mathrm{m}$ broad with a concave upper surface; intercalary, conidia were also observed. C. tropicum isolates formed pyriform, smoothwalled conidia of 6-8 $\mu \mathrm{m}$. The conidia of the isolate of $C$. keratinophilum were subhyaline, thick-walled obovoid with conspicuous basal scars, smooth-walled or slightly rough-walled. Sepedonim sp. formed yellowish orange colored colonies; microscopically characteristic globose spiny macroconidia were observed.

\section{DISCUSSION}

Investigators from several countries have reported on the occurrence of a variety of keratinophilic fungi including dermatophytes in soils of varying habitats. The predominant keratinophilic fungi reported in most studies include Chrysosporium spp (mainly $C$. indicum, $C$. tropicum and C. keratinophilum) and the dermatophyte $M$. gypseum $^{2-5,10-13,16,22}$. There have been only a few studies on the geophilic keratinophilic fungi from the Caribbean region. One study dealt with the recovery of a few isolates of M. gypseum, M. nanum, Trichophyton mentagrophytes, T. terrestre, and $C$. indicum from soil in Abaco Island in the Commonwealth of the Bahamas ${ }^{22}$, and another reported the isolation of Chrysosporium indicum and C. evolceanui from the soil of $\mathrm{Cuba}^{16}$. The third one was a comprehensive investigation on the distribution of M. gypseum and other keratinophilic fungi in soils of varying habitats in St. Kitts and Nevis ${ }^{12}$. The present study is the first of its kind from Jamaica. A very high incidence of $M$. gypseum complex demonstrated in the soils of Jamaica (50\%) is a noteworthy finding of public health significance. A similar high incidence (40\%) of M. gypseum complex has been recorded in the soils of Nevis ${ }^{12} \cdot M$. gypseum has also been found to occur frequently in soils of Brazil, 20.8\% in one survey ${ }^{2}$, and $19.2 \%$ in another very recent study of 692 samples from different geographic regions of the country ${ }^{8}$. The distribution of geophilic dermatophytes is influenced by soil $\mathrm{pH}$ and climatic factors. In a study from Kenya, the majority of the isolates of dermatophytes including $M$. gypseum were recovered from soils with acidic $\mathrm{pH}^{14}$. In another study from Brazil ${ }^{2}$, the majority of the isolates of $M$. gypseum were recovered from soils with almost neutral $\mathrm{pH}$ i.e. 7.0-7.09. A high prevalence of $M$. gypseum complex in soils of Nevis and Jamaica can be attributed mainly to tropical humid climate, a temperature of $22-30{ }^{\circ} \mathrm{C}$ for most of the year and the acidic $\mathrm{pH}$ of the soils in these islands.

The frequent occurrence of Chrysosporium as a geophilic keratinophilic fungus in Jamaican soil is in agreement with that recorded in surveys of keratinophilic fungi of soils in several other countries ${ }^{4,5,10-13}$. Our knowledge of ecology and epidemiology of dermatophytes and the factors influencing their transmission has helped us understand better the natural history of dermatophytoses. Human infections due to the geophilic dermatophyte, $M$. gypseum complex are infrequently or rarely known, particularly in the Caribbean region. In one study of the etiological agent of tinea capitis in Jamaica during 1998-2002, M. gypseum was represented by only one isolate ${ }^{6}$. Also in a similar study in Haiti, only one of the 55 isolates of dermatophytes was identified as M. gypseum $^{17}$. Comprehensive studies may reveal many more cases of skin and scalp infections due to M. gypseum.

\section{RESUMO}

Estudo preliminar sobre a ocorrência de fungos queratinofílicos em solos da Jamaica

Esta comunicação representa o primeiro estudo sobre fungos queratinofílicos presentes em solos da Jamaica. De 40 amostras de solo examinadas de diferentes localidades, $30(75 \%)$ foram positivas para a presença de fungos queratinofílicos permitindo 36 isolamentos dos mesmos. O complexo Microsporum gypseum (representados por 16 isolamentos de M. gypseum e quatro de M. fulvum) foi o mais frequente, estando presente em $50 \%$ das amostras. A muito alta ocorrência deste dermatófito no solo da Jamaica é significante para a saúde pública. Os isolados remanescentes de fungos queratinofílicos foram representados pelo Chrysosporium spp (principalmente $C$. indicum e C. tropicum) e Sepedonium $\mathrm{sp}$.

\section{REFERENCES}

1. Al-Doory Y. The occurrence of keratinophilic fungi in Texas soil. Mycopathol Mycol Appl. 1967;33:105-12. 
2. Da Silva Pontes ZB, Oliveira AC. Dermatophytes from urban soils in João Pessoa, Paraíba, Brazil. Rev Argent Microbiol. 2008;40:161-3

3. De Hoog GS, Guarro J, Gene J, Figueras MJ. Atlas of clinical fungi. $2^{\text {nd }}$ ed. Utrecht: Centraalbureau voor Schimmelcultures; 2000.

4. Deshmukh SK. Keratinophilic fungi isolated from soils of Mumbai, India. Mycopathologia. 1999;146:115-6.

5. Deshmukh SK, Verekar SA. The occurrence of dermatophytes and other keratinophilic fungi from the soils of Himachal Pradesh (India). Czech Mycol. 2006;58:117-24.

6. East-Innis A, Rainford L, Dunwell P, Barrett-Robinson D, Nicholson AM. The changing pattern of Tinea capitis in Jamaica. West Indian Med J. 2006;55:85-8.

7. Ellis D, Davis S, Alexiou H, Handke R, Bartley R. Descriptions of medical fungi, Mycology Unit, Women's and Children's Hospital, and School of Molecular and Biomedical Science, University of Adelaide. Adelaide: University of Adelaide; 2007. p. $42-94$

8. Giudice MC, Reis-Menezes AA, Rittner GM, Mota AJ, Gambale W. Isolation of Microsporum gypseum in soil samples from different geographical regions of Brazil, evaluation of the extracellular proteolytic enzymes activities (keratinase and elastase) and molecular sequencing of selected strains. Braz J Microbiol. 2012;43:895-902.

9. Gugnani HC, Shrivastav JB, Gupta NP. Occurrence of Arthroderma simii in soil and on hair of small mammals. Sabouraudia. 1968:6:77-80.

10. Gugnani HC. Non-dermatophytic filamentous keratinophilic fungi and their role in human infections. In: Kushwaha RK, Guarro J, editors. Biology of dermatophytes and other keratinophilic fungi. Bilbao: Berekintza; 2000. p. 109-14.

11. Gugnani HC, Paliwal-Joshi A, Rahman H, Padhye AA, Singh TS, Das TK, et al. Occurrence of pathogenic fungi in soil of burrows of rats and of other sites in bamboo plantations in India and Nepal. Mycoses 2007;50:507-11.

12. Gugnani HC, Soni S, Gupta B, Gaddam S. Prevalence of keratinophilic fungi in soils of St. Kitts and Nevis. J Infect Dev Ctries. 2012;6:347-51.
13. Kaul S, Sumbali G. Keratinophilic fungi from poultry farm soils of Jammu, India. Mycologist. 2000; 14:89-91.

14. Muhammed SI, Lalji N. The distribution of geophilic dermatophytes in Kenyan soils Mycopathologia. 1978;63:95-7.

15. Padhye AA, Summerbell RC. Dermatophytes. In: Merz WG, Hay J, editors. Topley \& Wilson's microbiology and microbial infections. $10^{\text {th }}$ ed. London: Arnold; 2010. v.6, p. 220-39

16. Otcenásek M, Hubálek Z, Dvorák J, Kunert J Chrysosporium indicum-like and Chrysosporium evolceanui from the soil of Cuba. Mykosen. 1968;11:19-24.

17. Raccurt CP, Dorsainvil D, Boncy M, Boncy J, Auguste G. The emergence of Trichophyton tonsurans in Port-au-Prince, Haiti. Med Mycol. 2009;47:197-200.

18. Sharma R, Presber WB, Rajak RC, Gräser Y. Molecular detection of Microsporum persicolor in soil suggesting widespread dispersal in central India. Med Mycol. 2008;46:67-73.

19. Summerbell RC. Form and function in the evolution of dermatophytes. In: Kushwaha RK, Guarro J, editors. Biology of dermatophytes and other keratinophilic fungi. Bilbao: Berekintza; 2000. p. 30-43.

20. van Oorschot CA. A revision of Chrysosporium and allied genera. Baarn Centraalbureau voor Schimmelcultures; 1980.89 p. (CBS studies in mycology; $n$. 28)

21. Vanbreuseghem R. Technique biologique pour l'isolement des dermatophytes du sol. Ann Soc Belge Med Trop. 1952;32:173-8.

22. Volz PA. A preliminary study of the keratinophilic fungi from Abaco Island, The Bahamas. Mycopathol Mycol Appl. 1971;43:337-9.

Received: 14 March 1913

Accepted: 9 October 1913 